\title{
Migratory linkages of Pacific Golden-Plovers Pluvialis fulva breeding in Chukotka, Russian Far East
}

\author{
Oscar W. Johnson' ${ }^{1}$ Pavel S. Tomkovich², Ronald R. Porter ${ }^{3}$, Egor Y. Loktionov ${ }^{4} \&$ Roger H. Goodwill ${ }^{5}$ \\ ${ }^{1}$ Dept. of Ecology, Montana State University, Bozeman, MT 59717, USA. owjohnson2105@aol.com \\ ${ }^{2}$ Zoological Museum, M.V. Lomonosov Moscow State University, Bolshaya Nikitskaya Str., 6, Moscow, 125009, Russia \\ ${ }^{3} 800$ Quinard Court, Ambler, PA 19002, USA \\ ${ }^{4}$ N.E. Bauman Moscow State Technical University, 2nd Baumanskaya Str., 5, Moscow, 105005, Russia \\ ${ }^{5}$ Dept. of Natural Sciences, Brigham Young University-Hawaii, Laie, HI 96762, USA
}

Johnson, O.W., P.S. Tomkovich, R.R. Porter, E.Y. Loktionov \& R.H. Goodwill. 2017. Migratory linkages of Pacific Golden-Plovers Pluvialis fulva breeding in Chukotka, Russian Far East. Wader Study 124(1): 33-39.

For the first time, we have tracked the annual migrations of Pacific GoldenPlovers nesting in northern Russia. We used geolocators to determine the timing and migration routes of four male plovers trapped at one site in SE Chukotka. Before leaving the north in autumn, each bird moved from nesting grounds and made one or two pre-migratory stopovers of 13-22 days (presumably on coastal tundra) in either Russia (Kamchatka and Khabarovsk Krai) or the USA (St. Matthew Island and the Pribilof Islands). After departing these sites, three birds traveled southward via eastern Asia and Japan to non-breeding grounds in the Philippine Islands, and one bird followed an oceanic route to Majuro Atoll in the Marshall Islands. All of these linkages were previously unknown. Two birds made nonstop flights of 4-6 days directly to non-breeding grounds, whereas two made additional stopovers en route ( $16 \mathrm{~d}$ in Japan and $18 \mathrm{~d}$ in China, respectively). In spring, return migrations from the Philippines variously included stopovers in South Korea, Taiwan, and China; the bird migrating from Majuro stopped-over only in Japan. Mean minimum flight speed on all legs in both autumn (after premigratory stopovers) and spring was $53 \mathrm{kph}$. On average, plovers spent 24 days at stopovers during the autumn journey, and 36 days at stopovers during the spring passage. Stopover sites and also non-breeding grounds probably included agricultural lands, most likely rice fields. While the migrations of these four birds shed light on migratory connectivity of Pacific Golden-Plovers nesting in Chukotka, additional studies are needed to: (1) further explore the non-breeding range of plovers breeding there and elsewhere in northern Russia, (2) better define important stopover sites including pre-migratory sites in the north, and (3) more fully understand the relationships between plovers and trophic resources associated with agriculture.

\section{Keywords}

Pacific Golden-Plover

Pluvialis fulva

Chukotka

geolocator

migration

flight speed

connectivity

stopovers

rice fields

\section{INTRODUCTION}

Pacific Golden-Plovers Pluvialis fulva nest on tundra from western Alaska across northern Russia to the Yamal Peninsula, and winter on inland and coastal habitats of the insular Pacific, Australia, New Zealand, SE Asia, India and NE Africa (Hayman et al. 1986, Johnson \& Connors 2010, Lappo et al. 2012). In these vast regions, knowledge of the species' migratory movements, migration strategies and winter range connectivity is limited mostly to studies conducted in Alaska, Hawaii, and a few locations in
Oceania. As for the Russian Far East, nothing was known concerning the routes, stopovers, and non-breeding grounds of plovers (see Tomkovich 2003) until recently when: (1) birds wintering at Saipan in the Mariana Islands (East Asian-Australasian Flyway) were tracked to breeding grounds in Chukotka and Kamchatka (Johnson et al. 2012), (2) plovers from Kwajalein Atoll in the Marshall Islands (mid-Pacific Flyway) were tracked to Chukotka (Johnson et al. 2015), and (3) a plover flagged at its nest in SE Chukotka was observed for two consecutive seasons at Darwin, Northern Territory, Australia (PST unpubl. 
(A)

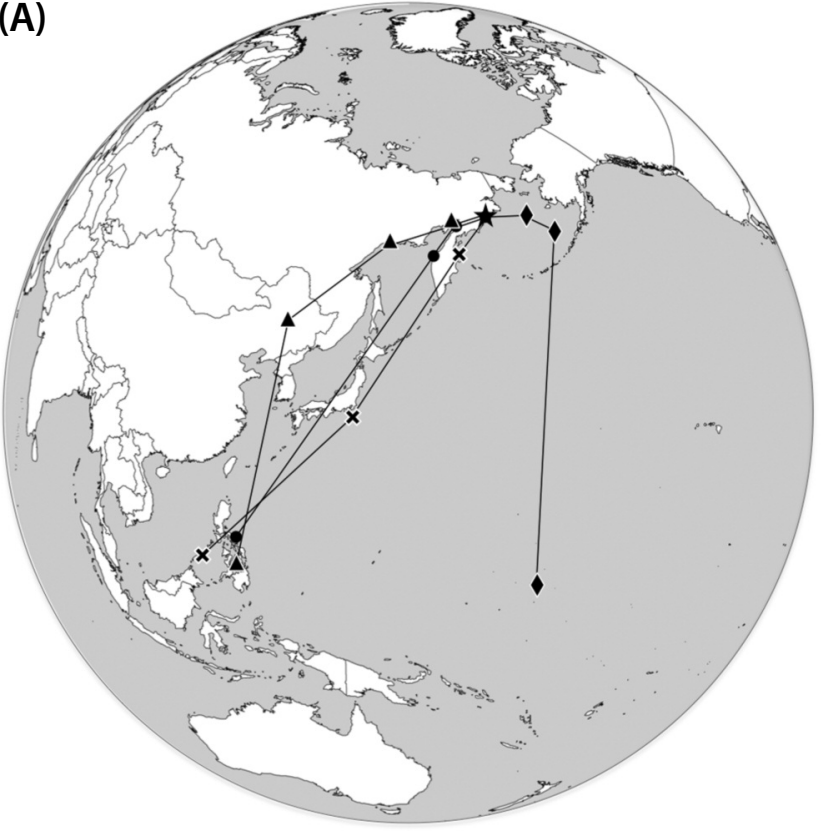

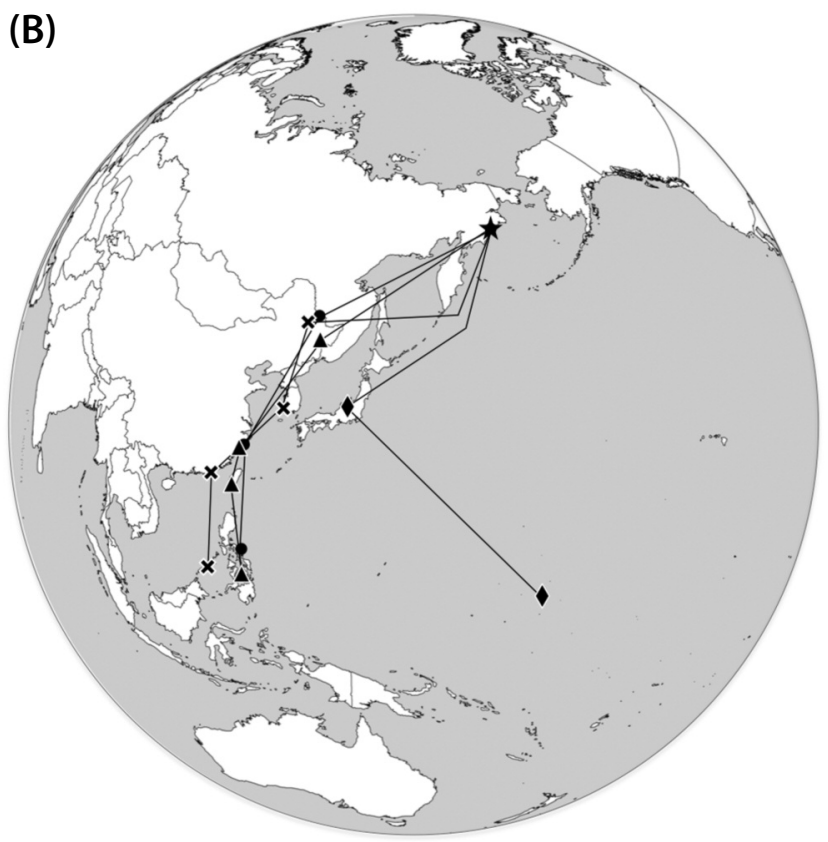

(B)

Fig. 1. The migratory tracks $(A=$ southward/autumn migration; $B=$ northward/spring migration) of four geolocatorequipped Pacific Golden-Plovers captured on nesting grounds near Meinypilgyno Village $(\star)$ in SE Chukotka, Russia. Symbols ( $\boldsymbol{x}=$ Plover No. $1 ; \boldsymbol{\theta}=$ No. $2 ; \boldsymbol{\Delta}=$ No. $3 ; \boldsymbol{*}=$ No. 4 ) indicate locations of stops.

data). Here we augment those findings with the first geolocator tracking of plovers captured on nesting grounds in Chukotka. These data substantially expand our knowledge of the winter range distribution of Pacific Golden-Plovers migrating from Chukotka and the annual routes they follow between breeding and non-breeding grounds.

\section{METHODS}

We trapped 14 Pacific Golden-Plovers on their nests at a study site in SE Chukotka, Russia near Meinypilgyno Village $\left(62.54^{\circ} \mathrm{N}, 177.05^{\circ} \mathrm{E}\right.$; Fig. 1), and fitted them with light-level geolocators (archival data loggers). We deployed the loggers in June and July, and recovered them a year later when the plovers were again nesting (Table 1). We captured plovers using a self-triggering clap-net (Priklonsky 1960). Two of four males were recaptured using the same technique, and two were collected by shooting (under permit issued to PST by authorities in Chukotka). The latter birds were escorting partly grown chicks when found, and therefore were impossible to recapture by conventional means. Subsequent observations indicated that the two females absent their mates continued to guard and brood their young, but whether the chicks successfully fledged is unknown.

We mounted geolocators on leg flags, using model Mk10b loggers (British Antarctic Survey, UK) in 2011, and Intigeo model W65 A9 (Migrate Technology, UK) in 2013. The flag plus the logger weighed $1.8 \mathrm{~g}$ (BAS units) or $1.1 \mathrm{~g}$ (Intigeos), both $<1 \%$ of probable average mass of plovers at migrations (Johnson \& Connors 2010). Our methodology for preparation and attachment of locators followed Johnson et al. $(2011,2012)$, with the exception that geolocators were mounted horizontally (instead of vertically) on the flags used in 2013. The data archived by the geolocators were analyzed using BasTrak software (British Antarctic Survey, UK) with procedures described by Porter \& Smith (2013).

Given the positional error inherent to geolocator technology, we emphasize that the only precise geographic locations in this paper are the GPS coordinates of the area where loggers were deployed and retrieved. To assess accuracy,

Table 1. Geolocators deployed on Pacific Golden-Plovers near Meinypilgyno Village, SE Chukotka, Russian Far East.

\begin{tabular}{|c|c|c|c|}
\hline$n$ deployed & Deployment period & $n$ recaptured ${ }^{*}$ & Recapture period \\
\hline 6 males, 2 females & 23 June-13 July 2011 & 1 male & 14 July 2012 \\
\hline 6 males & 21 June-6 July 2013 & 3 males & 13 June-13 July 2014 \\
\hline
\end{tabular}


we calculated distances over two seasons between geolocator fixes and known coordinates of the four plovers at their nesting sites and found longitude error ranging from 2 $\mathrm{km}$ ( $n=71$ fixes) to $72 \mathrm{~km}$ ( $n=39$ fixes), and latitude error when calibrated to the cluster edge (Porter \& Smith 2013) ranging from $14 \mathrm{~km}$ ( $n=71$ fixes) to $158 \mathrm{~km}(n=$ 31 fixes). Notably, the foregoing longitude deviations were similar to those reported for Red Knots Calidris canutus rogersi on nesting grounds (sympatric with the sample plovers) and during migrations (see Tomkovich et al. 2013). Overall, the measurements above suggest that $\pm 100 \mathrm{~km}$ accuracy is a reasonable assumption for the stopover and non-breeding locations described in this paper. All distance estimates are based on great circle calculations and thus the measurements are minimal. Estimates of minimum flight speeds represent the distance between departure and arrival points for each leg of the annual journey divided by the maximum flight time for each leg. The minimum annual distance traveled by each bird is the sum of all flights from its nest site to its nonbreeding grounds in autumn and return in spring.

\section{RESULTS}

Of the 14 birds equipped with geolocators (Table 1), four males and no females were found at our study site in subsequent years and their geolocators recovered. Because the loggers were not programmed for salt water detection, we were unable to determine whether the birds had used tidal flats during stopovers or at non-breeding grounds. The migratory tracks of the four males are shown in Fig. 1 , and using the symbols in the figure, the travels of each bird are chronicled in Box 1.

Before leaving the northern Pacific region in autumn, the plovers made relatively short flights (413-966 km) in order to reach pre-migratory stopover sites in Kamchatka, Khabarovsk Krai, St. Matthew Island, and the Pribilof Islands. These movements took a day or less, and where flights traversed land they may have included brief stops en route. All other flights, both autumn and spring (with the exception of Taiwan to the China coast by Plover 3) were substantially longer. After departure from the north, the migrations of Plovers 1, 2, and 3 traversed both continental and oceanic pathways, while the route followed by Plover 4 was entirely oceanic. Southward flights ranged from 2,091 km (Plover 3) to $>5,000 \mathrm{~km}$, the two longest being non-stop oceanic passages by Plover 2 from Kamchatka to the Philippines (5,644 km over about 4-5 days) and Plover 4 from the Pribilofs to Majuro (5,786 km over about 5-6 days). Northward flights leading to spring stopovers varied from $499 \mathrm{~km}$ (Plover 3) to $4,724 \mathrm{~km}$ (Plover 4), and final tracks to Chukotka from last stopovers in China and Japan ranged from 3,298 $\mathrm{km}$ (Plover 2) to $3,844 \mathrm{~km}$ (Plover 4). Overwater flights were non-stop, and overland legs appeared to be non-stop as well. Estimated mean minimum flight speed for all legs (those in autumn between nest sites and pre-migratory stopovers are not included) flown by the four birds was $53 \mathrm{kph}$ (SD \pm 11 ).
In autumn, pre-migration stopovers in the north ranged from 13 days (Plovers 1 and 3) to 22 days (Plover 4). During the subsequent migratory flight, Plovers 1 and 3 each made one additional stopover (16 and 18 days, respectively) before reaching non-breeding grounds; Plovers 2 and 4 flew non-stop. Aggregate stopover time prior to arrival on non-breeding grounds averaged 24 days (range $=16$ [Plover 2] to 31 days [Plover 3]). In spring, Plovers 1, 2, and 3 made two to three stopovers during their northward journeys, whereas Plover 4 stopped only in Japan. Notably, Plovers 2 and 3 stopped-over in the same coastal region in eastern China. While en route north, aggregate stopover time per individual averaged 36 days (range $=24$ [Plover 4] to 45 days [Plover 2]). The aggregate times spent stopping-over during autumn and spring migrations were not significantly different $(P=$ 0.082).

Each of the four plovers was visually monitored following attachment of its geolocator. All of the birds continued incubation and hatched chicks. Hatching dates were 6 July for the single bird in 2011, and 2-4 July for the three birds in 2013. Autumn departures from the nesting grounds occurred during 4-7 August (see Box 1); thus the interval between hatching and the start of autumn migration of the male parents was 29-36 days.

\section{DISCUSSION}

The findings reported here are the first of their kind for Pacific Golden-Plovers captured on breeding grounds in northern Russia. To previously known linkages (SaipanChukotka, Saipan-Kamchatka, Kwajalein-Chukotka, Chukotka-Australia; Johnson et al. 2012, 2015, PST unpubl. data), we can now add Chukotka-Philippine Islands (Plovers 1, 2, and 3) and Chukotka-Majuro Atoll (Plover 4). Clearly, the non-breeding grounds of Pacific Golden-Plovers nesting in the Russian Far East span a vast area of the world from at least $171^{\circ} \mathrm{E}$ to $118^{\circ} \mathrm{E}$ (Majuro to Palawan) and $9^{\circ} \mathrm{N}$ to $12^{\circ} \mathrm{S}$ (Kwajalein to Darwin).

Given the lack of data concerning contact with saltwater, we are unable to assess the possible use of tidal habitats during migrations and wintering. However, we suspect that the birds' primary foraging habitats were inland, and base this on the species' strong preference for uplands as evidenced by: (1) the scarcity of plovers in shorebird aggregations on mudflats in the north and along the Asian coast including China (Gerasimov 2003, Gerasimov et al. 2016, sources in Johnson \& Connors 2010, Lappo et al. 2012), (2) the concentration of plovers at inland sites during stopovers in Mongolia and Japan (Wijmenga et al. 2011, Johnson et al. 2015), (3) the nature of nonbreeding grounds as described in other studies (Johnson et al. 2006, 2008, Johnson \& Connors 2010), (4) the satellite transmitter-equipped Pacific Golden-Plover that wintered at Sulawesi (see below) in an area with many rice fields, (5) the use of croplands by plovers in China (Zhao 2001, Wang et al. 2006), and (6) the inland foraging behavior of the world's other two species of goldenplovers (Eurasian P. apricaria and American P. dominica; 
Byrkjedal \& Thompson 1998, Johnson \& Connors 2010, Stodola et al. 2014). Furthermore, where geolocator fixes of our sample birds indicated shorelines as possible stopover or wintering habitat there were also potential inland habitats (as visualized with Google Earth) situated nearby well within the margin of error. These consisted of coastal tundra in the north and agricultural lands (typically rice fields) elsewhere. The latter were often interspersed with villages and other human development producing a somewhat urbanized landscape comparable to non-breeding habitats in Hawaii and elsewhere in the Pacific (Johnson \& Connors 2010). Of the four stopover sites in NE China (see Box 1) three were far enough inland $(>600 \mathrm{~km})$ to exclude the possibility of coastal feeding; one site (at about $250 \mathrm{~km}$ ) was less certain.
The autumn stopovers of Plovers 2 and 3 in the Penzhina Gulf region (northern Sea of Okhotsk) were in an area where large pre-migratory aggregations of shorebirds occur on extensive tidal flats. As mentioned above, Pacific Golden-Plovers are relatively scarce in these gatherings, which suggests that plovers tend to favor coastal tundra uplands instead of shorelines as they prepare for southbound migration. Comparable findings during autumn migration in Alaska are mixed: on the Alaska Peninsula, Gill et al. (1981) reported that plovers (adults and juveniles) "preferred intertidal areas and were recorded away from there on only two occasions", whereas on the YukonKuskokwim Delta, Gill \& Handel (1990) found only juvenile plovers using intertidal habitats. Current knowledge of pre-migratory stopover times in the north indicates

Box 1. Migration chronologies of four geolocator-tracked Pacific Golden-Plovers from Chukotka. Symbols refer to tracks shown in Fig. 1.

\section{Plover No. 1 (*)}

4 August 2011, departed nesting grounds, stopped-over in E Kamchatka $58.1^{\circ} \mathrm{N}, 161.9^{\circ} \mathrm{E}$ (966 km) for 13 days until 18 August. 20 August, arrived at Kojima Island, Japan, $33.1^{\circ} \mathrm{N}, 139.8^{\circ} \mathrm{E}(3,236 \mathrm{~km})$, stopped-over for 16 days until 5 September. 8 September, arrived Palawan Island, Philippines $9.4^{\circ} \mathrm{N}, 118.1^{\circ} \mathrm{E}(3,447 \mathrm{~km})$ and wintered, departed on northward migration 13 April 2012. 14 April, arrived in SE China $25.9^{\circ} \mathrm{N}, 116.1^{\circ} \mathrm{E}$ $(1,851 \mathrm{~km})$, stopped-over for 22 days until 6 May. 7 May, arrived South Korea $34.4^{\circ} \mathrm{N}, 126.1^{\circ} \mathrm{E}(1,351 \mathrm{~km})$, stopped-over for 4 days until 11 May. 12 May, arrived NE China $47.5^{\circ} \mathrm{N}, 127.0^{\circ} \mathrm{E}(1,459 \mathrm{~km})$, stopped-over for 8 days until 20 May. Made direct flight back to Chukotka nest site $(3,483 \mathrm{~km})$, final tracking was overwater east of the Kamchatka Peninsula, arrived 23 May. Minimum round-trip distance traveled = 15,793 km.

\section{Plover No. 2 (O)}

7 August 2013, departed nesting grounds, stopped-over at Kamchatka isthmus (eastern side of Penzhina Gulf) $61.9^{\circ} \mathrm{N}, 164.5^{\circ} \mathrm{E}(653 \mathrm{~km})$ for 4 days until 12 August. Shifted to western Kamchatka $57.8^{\circ} \mathrm{N}, 157.1^{\circ} \mathrm{E}(618$ $\mathrm{km})$, stopped-over for 12 days until 25 August. 29 August, arrived Luzon Island, Philippines $14.2^{\circ} \mathrm{N}, 122.4^{\circ} \mathrm{E}$ (5,644 km) and wintered, departed on northward migration 2 April 2014. 3 April, arrived east coast of China $27.6^{\circ} \mathrm{N}, 120.6^{\circ} \mathrm{E}(1,496 \mathrm{~km})$, stopped-over for 33 days until 6 May. 8 May, arrived NE China $49.1^{\circ} \mathrm{N}, 128.0^{\circ} \mathrm{E}$ (2,484 km), stopped-over for 12 days until 20 May. Made direct flight back to Chukotka nest site $(3,298 \mathrm{~km})$, arrived 24 May. Minimum roundtrip distance traveled $=14,193 \mathrm{~km}$.

\section{Plover No. $3(\mathbf{\Lambda})$}

7 August 2013, departed nesting grounds and stopped-over at Kamchatka isthmus (eastern side of Penzhina Gulf) $60.7^{\circ} \mathrm{N}, 162.9^{\circ} \mathrm{E}(774 \mathrm{~km})$ for 8 days until 16 August. Shifted to NE Khabarovsk Krai close to border with Magadan Oblast $59.5^{\circ} \mathrm{N}, 146.6^{\circ} \mathrm{E}(913 \mathrm{~km})$, stopped-over for 5 days until 22 August. 24 August, arrived NE China $46.2^{\circ} \mathrm{N}, 124.2^{\circ} \mathrm{E}(2,091 \mathrm{~km})$, stopped-over for 18 days until 10 September. 13 September, arrived Philippines (probably Bohol Island) $10.0^{\circ} \mathrm{N}, 124.1^{\circ} \mathrm{E}(4,027 \mathrm{~km})$ and wintered, departed on northward migration 2 April 2014. 3 April, arrived Taiwan $23.1^{\circ} \mathrm{N}, 120.0^{\circ} \mathrm{E}(1,523 \mathrm{~km})$, stopped-over for 19 days until 22 April. 23 April, arrived east coast of China $27.6^{\circ} \mathrm{N}, 120.6^{\circ} \mathrm{E}(499 \mathrm{~km})$, stopped-over for 11 days until 4 May. 6 May, arrived NE China $45.4^{\circ} \mathrm{N}, 131.5^{\circ} \mathrm{E}(2,207 \mathrm{~km})$, stopped-over for 13 days until 19 May. Made direct flight back to Chukotka nest site $(3,430 \mathrm{~km})$, arrived 22 May. Minimum roundtrip distance traveled $=15,464 \mathrm{~km}$.

\section{Plover No. $4(\diamond)$}

7 August 2013, departed nesting grounds, stopped-over at St. Matthew Island $60.4^{\circ} \mathrm{N}, 172.7^{\circ} \mathrm{W}(593 \mathrm{~km})$ for 8 days until 16 August, shifted to Pribilof Islands $57.0^{\circ} \mathrm{N} 169.8^{\circ} \mathrm{W}(413 \mathrm{~km})$, stopped-over for 14 days until 30 August. 4 September, arrived Majuro Atoll, Marshall Islands $7.1^{\circ} \mathrm{N}, 171.4^{\circ} \mathrm{E}(5,786 \mathrm{~km})$ and wintered (probably at the international airport), departed on northward migration 20 April 2014. 24 April, arrived Honshu Island, Japan $37.2^{\circ} \mathrm{N}, 138.4^{\circ} \mathrm{E}(4,724 \mathrm{~km})$, stopped-over for 24 days until 18 May. Made direct flight back to Chukotka nest site $(3,844 \mathrm{~km})$, arrived 21 May. Minimum roundtrip distance traveled $=15,360 \mathrm{~km}$. 
wide variation: 13-22 days in this study, and 1-40 days in Alaska (Johnson et al. 2011, 2012).

The association of Pacific Golden-Plovers with inland stopover sites, which is well documented in Mongolia (Wijmenga et al. 2011) and NE China (this study; L. Tibbitts \& OWJ unpubl. data), is in sharp contrast to numerous species of shorebirds that depend on tidal wetlands for refueling during long-distance migrations (e.g., Red Knots, Tomkovich et al. 2013; Sanderlings C. alba, Lisovski et al. 2016). Foraging in agricultural fields is not without potential hazards including chemical contamination (Parsons et al. 2010) and new farming practices that are less bird-friendly. Nonetheless, these lands may constitute a more reliable long-term resource as compared to vulnerable coastal habitats that are rapidly being destroyed (MacKinnon et al. 2012, Murray et al. 2014, 2015). Many plovers refuel in Japan, especially Honshu Island (Bamford et al. 2008, Johnson et al. 2012, 2015), and the 24-day spring stopover of Plover 4 there matched both the location and duration reported for birds previously tracked from the Central Pacific (average 23 days, range $=15-28$ days; Johnson et al. 2015).

As for other geolocator applications involving waders in northern Russia, only the migrations of three Red Knots nesting in the same area as the foregoing plovers (near Meinypilgyno Village, Chukotka) have been tracked (Tomkovich et al. 2013). The geolocator-equipped knots migrated to more distant non-breeding grounds (Australia and New Zealand) than the sampled plovers, and thus their roundtrips were longer, from 23,000 to $31,000 \mathrm{~km}$, with non-stop flight legs up to $10,100 \mathrm{~km}$ and 8 days duration at flight speeds averaging $52.5 \mathrm{kph}$. That plovers share similar capabilities for long-distance flight is indicated by various findings: (1) previous geolocator tracking by Johnson et al. (2012, 2015), (2) the marked plover mentioned above that was observed at Darwin, (3) three plovers banded at Nome, Alaska and sighted in Queensland, Australia (OWJ unpubl. data), and (4) a satellite transmitter-equipped plover nesting near Nome that made a non-stop flight of at least $11,100 \mathrm{~km}$ from Alaska to Okinawa over 8.5 days. This last bird flew nearly to Hawaii, then turned west (minimum flight speed $=54$ $\mathrm{kph}$ ), went on to winter in southeast Sulawesi, then returned to its nesting territory via the Philippines, China, and Russia for a round trip migration of $27,360 \mathrm{~km}$ (L. Tibbitts \& OWJ unpubl. data). Estimated mean minimum flight speed of the four plovers in the present study (53 $\mathrm{kph}, \mathrm{SD} \pm 11$ ) closely matched the estimate for Red Knots mentioned above, fell within previous speed estimates for the species (Johnson et al. 2011, 2012, 2015), and was similar to estimates of speeds during non-stop flights of other shorebirds (Driscoll \& Ueta 2002, Gill et al. 2009, Minton et al. 2010, 2011, 2013, Klaassen et al. 2011, Battley et al. 2012, Niles et al. 2012).

The Pacific Golden-Plovers' breeding range in Russia spans about 4,300 km from eastern Chukota westward to the Yamal Peninsula (roughly $170^{\circ} \mathrm{W}$ to $70^{\circ} \mathrm{E}$; Lappo et al. 2012), and except for the connectivity described in this paper there are no other records linking plovers nesting in this region with non-breeding grounds. While insight gained by tracking the migrations of four plovers nesting in Chukotka is valuable from a conservation perspective, these birds represent only a small part of the breeding grounds and much remains to be learned.

The species' non-breeding range is enormous (see Introduction), and it is likely that plovers migrating from Chukotka are among wintering flocks on islands and atolls aside from those mentioned above. Clearly, additional tracking with geolocators or other technology is needed to better define the entire non-breeding range that supports the Chukotka population. Ideally, similar studies should be conducted in other parts of northern Russia where linkages are currently unknown. Resources gleaned from agricultural fields may be vital for migrating and wintering plovers, and we encourage observations in areas revealed by this study (also see locations listed by Bamford $e t$ al. 2008) to clarify the use of such habitats at stopover sites and wintering grounds. Based on the criteria proposed by Warnock (2010), some of the stopovers that we list above, particularly last stops before the final passage to non-breeding or breeding grounds, might be staging areas of high conservation importance. Finally, there is the question of habitat use (intertidal vs. upland tundra) at pre-migratory autumn stopovers. Fieldwork is needed to more fully understand this phase of the plovers' annual cycle, and to assess possible age-related habitat preferences.

\section{ACKNOWLEDGEMENTS}

This study was undertaken within the framework of the International Arctic Expedition of Birds Russia organized by Evgeny E. Syroechkovskiy and funded from multiple sources. Involvement of PST was supported by Russian Science Foundation project No. 14-50-00029. We thank Tong $\mathrm{Mu}$ for information pertaining to bird use of rice fields in China. We are grateful to Dan Ruthrauff, Nils Warnock, and Jesse Conklin for many helpful comments and suggestions on the manuscript.

\section{REFERENCES}

Bamford, M, D. Watkins, W. Bancroft, G. Tischler \& J. Wahl. 2008. Migratory Shorebirds of the East Asian-Australasian Flyway: Population Estimates and Internationally Important Sites. Wetlands International - Oceania, Canberra, Australia.

Battley, P.F., N. Warnock, T.L. Tibbits, R.E. Gill, Jr., T. Piersma, C.J. Hassell, D.C. Douglas, D.M. Mulcahy, B.D. Gartrell, R. Schuckard, D.S. Melville \& A.C. Riegen. 2012. Contrasting extreme long-distance migration patterns in bar-tailed godwits Limosa lapponica. Journal of Avian Biology 43: 21-32.

Byrkjedal, I. \& D. Thompson. 1998. Tundra plovers: The Eurasian, Pacific and American Golden Plovers and Grey Plover. T \& AD Poyser Ltd., London.

Driscoll, P.V. \& M. Ueta. 2002. The migration route and behaviour of Eastern Curlews Numenius madagascariensis. Ibis 144: E119-130. 
Gerasimov, Y. 2003. Shorebird studies in North Kamchatka from July 5-August 12 2002. Stilt 44: 19-28.

Gerasimov, Y.N., I.M. Tiunov, A.I. Matsyna \& R.V. Bukhalova. 2016. Bolsaya Vorovskaya River Lagoon as a stopover site of international importance for shorebirds. Pp. 125-129 in: Issues of Wader Ecology, Migration and Conservation in Northern Eurasia: Materials of the 10th Jubilee Conference of the Working Group on Waders of Northern Eurasia. (I.I. Chernichko \& V.N. Mel'nikov, Eds.). Ivanovo State University, Russia. [In Russian with English summaries]

Gill, R.E., Jr., M.R. Petersen \& P.D. Jorgensen. 1981. Birds of the northcentral Alaska Peninsula, 1976-1980. Arctic 34: 286-306.

Gill, R.E., Jr. \& C.M. Handel. 1990. The importance of subarctic intertidal habitats to shorebirds: A a study of the Central Yukon-Kuskokwim Delta, Alaska. Condor 92: 709-725.

Gill, R.E., Jr., T.L. Tibbitts, D.C. Douglas, C.M. Handel, D.M. Mulcahy, J.C. Gottschalck, N. Warnock, B.J. McCaffery, P.F. Battley \& T. Piersma. 2009. Extreme endurance flights by landbirds crossing the Pacific Ocean: ecological corridor rather than barrier? Proceedings of the Royal Society B: Biological Sciences 276: 447-457.

Hayman, P., J. Marchant \& T. Prater. 1986. Shorebirds: An Identification Guide to the Waders of the World. Houghton Mifflin, Boston.

Johnson, O.W., R. Goodwill \& P.M. Johnson. 2006. Wintering ground fidelity and other features of Pacific GoldenPlovers Pluvialis fulva on Saipan, Mariana Islands, with comparative observations from Oahu, Hawaiian Islands. Wader Study Group Bulletin 109: 67-72.

Johnson, O.W., R.H. Goodwill, A.E. Bruner, P.M. Johnson, R.S. Gold, R.B. Utzurrum \& J.O. Seamon. 2008. Pacific Golden-Plovers Pluvialis fulva in American Samoa: spring migration, fall return of marked birds, and other observations. Wader Study Group Bulletin 115: 20-23.

Johnson, O.W. \& P.G. Connors. 2010. Pacific Golden-Plover (Pluvialis fulva). In: The Birds of North America Online (P. G. Rodewald, Ed.). Cornell Lab of Ornithology, Ithaca, NY. Accessed at: https://birdsna.org/Species-Account/bna/ species/202.

Johnson, O.W., L. Fielding, J.W. Fox, R.S. Gold, R.H. Goodwill \& P.M. Johnson. 2011. Tracking the migrations of Pacific Golden-Plovers (Pluvialis fulva) between Hawaii and Alaska: new insight on flight performance, breeding ground destinations, and nesting from birds carrying light level geolocators. Wader Study Group Bulletin 118: 26-31.

Johnson, O.W., L. Fielding, J.P. Fisher, R.S. Gold, R.H. Goodwill, A.E. Bruner, J.F. Furey, P.A. Brusseau, N.H. Brusseau, P.M. Johnson, J. Jukema, L.L. Prince, M.J. Tenney \& J.W. Fox. 2012. New insight concerning transoceanic migratory pathways of Pacific Golden-Plovers (Pluvialis fulva): the Japan stopover and other linkages as revealed by geolocators. Wader Study Group Bulletin 119: $1-8$.

Johnson, O.W., R.R. Porter, L. Fielding, M.F. Weber, R.S. Gold, R.H. Goodwill, P.M. Johnson, A.E. Bruner, P.A.
Brusseau, N.H. Brusseau, K. Hurwitz \& J.W. Fox. 2015. Tracking Pacific Golden-Plovers Pluvialis fulva: transoceanic migrations between non-breeding grounds in Kwajalein, Japan and Hawaii and breeding grounds in Alaska and Chukotka. Wader Study 122: 4-11.

Klaassen, R.H.G., T. Alerstam, P. Carlsson, J.W. Fox \& A. Lindström. 2011. Great flights by great snipes: long and fast non-stop migration over benign habitats. Biology Letters 7: 833-835.

Lappo, E.G., P.S. Tomkovich \& E.E. Syroechkovskiy. 2012. Atlas of Breeding Waders of the Russian Arctic. UF Ofsetnaya Pechat, Moscow. [In Russian with English summaries]

Lisovski, S., K. Gosbell, M. Christie, B.J. Hoye, M. Klaassen, I.D. Stewart, A.J. Taysom \& C. Minton. 2016. Movement patterns of Sanderling (Calidris alba) in the East AsianAustralasian Flyway and a comparison of methods for identification of crucial areas for conservation. Emu 116: 168-177.

MacKinnon, J., Y.I. Verkuil \& N. Murray. 2012. IUCN situation analysis on East and Southeast Asian intertidal habitats, with particular reference to the Yellow Sea (including the Bohai Sea). Occasional Paper of the IUCN Species Survival Commission No.47. IUCN, Gland, Switzerland and Cambridge, UK.

Minton, C., K. Gosbell, P. Johns, M. Christie, J.W. Fox \& V. Afanasyev. 2010. Initial results from light level geolocator trials on Ruddy Turnstones Arenaria interpres reveal unexpected migration route. Wader Study Group Bulletin 117: 9-14.

Minton, C., K. Gosbell, P. Johns, M. Christie, M. Klaassen, C. Hassell, A. Boyle, R. Jessop \& J. Fox. 2011. Geolocator studies on Ruddy Turnstones Arenaria interpres and Greater Sandplovers Charadrius leschenaultii in the East Asian-Australasian flyway reveal widely different migration strategies. Wader Study Group Bulletin 118: 87- 96.

Minton, C., K. Gosbell, P. Johns, M. Christie, M. Klaassen, C. Hassell, A. Boyle, R. Jessop, \& J. Fox. 2013. New insights from geolocators deployed on waders in Australia. Wader Study Group Bulletin 120: 37-46.

Murray, N.J., R.S. Clemens, S.R. Phinn, H.P. Possingham \& R.A. Fuller. 2014. Tracking the rapid loss of tidal wetlands in the Yellow Sea. Frontiers in Ecology \& Environment 12: 267-272.

Murray, N.J., Z. Ma \& R.A. Fuller. 2015. Tidal flats of the Yellow Sea: a review of ecosystem status and anthropogenic threats. Austral Ecology 40: 472-481.

Niles, L.J., J. Burger, R.R. Porter, A.D. Dey, S. Koch, B. Harrington, K. Iaquinto \& M. Boarman. 2012. Migration pathways, migration speeds and non-breeding areas used by northern hemisphere wintering Red Knots Calidris canutus of the subspecies rufa. Wader Study Group Bulletin 119: 195-203.

Parsons, K.C., P. Mineau \& R.B. Renfrew. 2010. Effects of pesticide use in rice fields on birds. Waterbirds 33 (Special Publ. 1): 193-218.

Porter, R. \& P.A. Smith. 2013. Techniques to improve the accuracy of location estimation using light-level geolocation to track shorebirds. Wader Study Group Bulletin 120: 147158 . 
Priklonsky, S.G. 1960. Use of automatic "luchock"-traps for bird catching. Zoologichesky Zhurnal 39: 623-624. [In Russian]

Stodola, K.W., B.J. O'Neal, M.G. Alessi, J.L. Deppe, T.R. Dallas, T.A. Beveroth, T.J. Benson \& M.P. Ward. 2014. Stopover ecology of American Golden-Plovers (Pluvialis dominica) in Midwestern agricultural fields. Condor 116: 162-172.

Tomkovich, P.S. 2003. List of wader species of Chukotka, northern Far East of Russia: their banding and migratory links. Stilt 44: 29-43.

Tomkovich, P.S., R.R. Porter, E.Y. Loktionov \& L.J. Niles. 2013. Pathways and staging areas of Red Knots Calidris canutus rogersi breeding in southern Chukotka, Far Eastern Russia. Wader Study Group Bulletin 120: 181-193.
Wang, Q., M. Ma \& Y. Gao. 2006. Fauna Sinica Aves, Vol. 5: Gruiformes, Charadriiformes and Lariformes. Science Press, Beijing. [In Chinese with English summaries]

Warnock, N. 2010. Stopping vs. staging: the difference between a hop and a jump. Journal of Avian Biology 41: 621-626.

Wijmenga, J.J., J. Jukema, J. Reneerkens, S. Gombobaatar, B. Gantulga \& S. Tserennadmid. 2011. The importance of North-Eastern Mongolia for migrating Pacific Golden Plovers. Spring 2005. Foundation Working Group International Waterbird \& Wetland Research (WIWO) Report 87. Nijmegen, The Netherlands.

Zhao, Z. 2001. A Handbook of the Birds of China. Jilin Science \& Technology Press, Changchun. [In Chinese] 